\title{
Pengembangan Perangkat Pembelajaran Matematika Terintegrasi Keterampilan Abad 21 Melalui Penerapan Model Problem Based Learning (PBL)
}

\author{
Mahmidatul Fitri ${ }^{1}$, Putri Yuanita ${ }^{2 *}$, Maimunah $^{3}$ \\ ${ }^{1,2,3}$ Universitas Riau, Pekanbaru, 28291, Indonesia
}

Pengiriman: 17/November/2019; Diterima: 24/Maret/2020; Publikasi: 31/Maret/2020

DOI: https://doi/org/10.31629/jg.v5i1.1609

\begin{abstract}
Abstrak
Kurikulum 2013 mulai menerapkan pembelajaran yang berorientasi pada pembelajaran abad 21. Tujuan dari penelitian ini adalah menghasilkan prototipe perangkat pembelajaran matematika terintegrasi keterampilan abad 21. Jenis penelitian yang dilakukan adalah penelitian pengembangan dengan menggunakan model Plomp. Penelitian ini terdiri dari tiga fase yaitu: (1) fase investigasi awal (preliminary research); (2) fase prototipe (prototyping phase); dan (3) fase penilaian (assessment phase). Hasil dari penelitian ini adalah prototipe perangkat pembelajaran matematika terintegrasi keterampilan abad 21 melalui penerapan model PBL untuk meningkatkan kemampuan berpikir tingkat tinggi yang salah satunya adalah kemampuan pemecahan masalah matematis peserta didik SMP/MTs. Hasil validasi silabus, RPP, LKPD dan soal kemampuan pemecahan masalah matematis menunjukkan kriteria sangat valid dengan nilai secara berurutan sebesar 3,51; 3,46; 3,48; dan 3,43. Hasil praktikalitas menunjukkan kriteria sangat praktis dengan persentase uji coba kelompok kecil sebesar 91,00\%, uji coba kelompok besar sebesar 92,50\%, dan respon guru sebesar 93,50\%.
\end{abstract}

Kata Kunci: keterampilan abad 21; kemampuan pemecahan masalah matematis; model PBL

\begin{abstract}
In 2013, the curriculum began to utilize learning-oriented learning in the 21st century. The purpose of this study is to create a prototype of a 21 st century technology integrated math learning device. The type of research carried out is development research using the Plomp model. This study consisted of three phases: (1) the initial investigation phase (preliminary research); (2) the prototype phase (prototyping phase); and (3) Level phase (assessment phase). The results of this study are a prototype of an integrated 21 st century mathematics learning tool through the application of PBL models to improve the ability to think highly, one of which is the problem solving ability of junior high school/MTs students. Results of syllabus, RPP, LKPD validation and mathematical problem solving abilities showed very valid criteria with sequential values of $3.51 ; 3.46 ; 3.48$; and 3.43 . The results of the try out were very practical with small group trials of $91.00 \%$, large group trials of $92.50 \%$, and teacher responses of $93.50 \%$.
\end{abstract}

Keywords: 21st century skills; mathematical problem solving ability; problem based learning model

\section{Pendahuluan}

Pendidikan merupakan

bentuk perwujudan kebudayaan manusia yang dinamis dan perkembangan dunia pendidikan adalah hal

Email Address: putri.yuanita@lecturer.unri.ac.id

Handphone : : +6281378035142 


\section{JURNAL GANTANG. Maret 2020; V(1): 77 - 85 \\ p-ISSN. 2503-0671 \\ e-ISSN. 2548-5547}

yang memang seharusnya terjadi sejalan dengan perubahan budaya kehidupan. Perubahan dalam arti perbaikan pendidikan pada semua tingkat perlu terus menerus dilakukan sebagai antisipasi kepentingan masa depan (Trianto, 2009). Pemerintah terus melakukan perubahan dan inovasi dalam bidang pendidikan kearah yang lebih baik, salah satunya adalah pembaharuan dan inovasi kurikulum, yakni lahirnya kurikulum 2013. Kurikulum 2013 mulai menerapkan pembelajaran yang berorientasi pada pembelajaran abad 21. Aji (2019) mengatakan bahwa pembelajaran abad 21 secara sederhana diartikan sebagai pembelajaran yang memberikan kecakapan abad 21 kepada peserta didik, yaitu keterampilan 4C yang meliputi: 1) Communication, 2) Collaboration, 3) Critical thinkingand Problem Solving, 4) Creativity and innovation. Salah satu ciri pembelajaran pada abad 21 adalah pembelajaran menuntut agar peserta didik memiliki kemampuan pemecahan masalah. Menurut Sugiyarti et al., (2018), penerapan konsep 4C dalam pembelajaran kurikulum 2013 memberikan dampak yang sangat besar bagi generasi penerus bangsa untuk menghadapi tantangan hidup abad 21.

Melalui pembelajaran matematika, kemampuan pemecahan masalah matematis merupakan salah satu kemampuan yang harus dimiliki oleh peserta didik. Pentingnya kemampuan pemecahan masalah oleh peserta didik dalam matematika menurut Branca (Sumarmo, 2014), yaitu: (1) kemampuan menyelesaikan masalah merupakan tujuan umum pengajaran matematika; (2) penyelesaian masalah yang meliputi model, prosedur dan strategi merupakan proses inti dan utama dalam kurikulum matematika; (3) penyelesaian masalah merupakan kemampuan dasar dalam belajar matematika.

Tujuan pembelajaran matematika dapat dicapai dengan merencanakan proses pembelajaran matematika yang sesuai. Menurut Kunandar (2014), guru yang baik harus menyusun perencanaan sebelum melaksanakan pembelajaran di kelas. Perencanaan pembelajaran dapat dirancang dalam bentuk perangkat pembelajaran. Peneliti melakukan observasi dan wawancara dengan enam orang guru matematika SMP di kota Pekanbaru. Wawancara yang dilakukan meliputi aspek pengembangan silabus, RPP, dan LKPD yang digunakan oleh guru dalam proses pembelajaran.

Hasil wawancara diperoleh informasi bahwa hanya satu orang guru yang mengembangkan perangkat dan menggunakannya dalam proses pembelajaran, sedangkan lima guru lainnya hanya menggunakan perangkat pembelajaran yang sudah ada. Perangkat pembelajaran yang sudah ada yang dimaksud adalah perangkat pembelajaran yang berasal dari teman, penerbit, download dari internet dan perangkat dari hasil Musyawarah Guru Mata Pelajaran (MGMP) matematika. Guru hanya memberikan contohcontoh soal yang ada dibuku paket khususnya pada KD yang menuntut pemecahan masalah. Selain itu guru kurang memfasilitasi peserta didik untuk dapat mengembangkan kemampuan pemecahan masalah matematis mereka.

Hasil studi pendahuluan tes soal kemampuan pemecahan masalah matematis pada materi statistika kepada peserta didik kelas VIII diperoleh salah satu gambaran bahwa peserta didik sudah dapat meentukan serta menuliskan apa yang diketahui dan yang ditanya dari soal, namun peserta didik kesulitan dalam menjawab soal. Peserta didik belum bisa dalam menentukan penyelesaian masalah dari soal tersebut dengan benar.

Salah satu bentuk persiapan yang harus dilakukan oleh guru dalam proses pembelajaran adalah perangkat pembelajaran (Putri et al., 2020). Perlu adanya inovasi pembelajaran matematika yang berpusat pada peserta didik, pembelajaran yang memberikan kesempatan kepada peserta didik untuk dapat meningkatkan aktivitas belajar peserta didik. Menurut Arends dalam (Trianto, 2009), Problem Based Learning (PBL) adalah suatu model pembelajaran yang menggunakan masalah dunia nyata sebagai suatu konteks bagi peserta didik untuk belajar tentang 
keterampilan pemecahan masalah. Sejalan dengan penelitian yang dilakukan oleh Noviantii et al., (2020) menyimpulkan bahwa model PBL meningkatkan kemampuan pemecahan masalah matematis peseta didik kelas VII 2 SMPN 9 Pekanbaru.

Dalam model PBL, masalah yang diajukan oleh guru adalah permasalahan dunia nyata, sehingga peserta didik dilatih untuk memecahkan masalah yang membutuhkan pemikiran kreatif. Materi Statistika merupakan salah satu materi pokok yang diajarkan di SMP/MTs.

Berdasarkan hasil kajian terhadap perangkat pembelajaran yang digunakan oleh guru dalam proses pembelajaran, terhadap silabus, RPP dan LKPD yang digunakan oleh guru mata pelajaran matematika di sekolah pada materi Statistika kelas VIII tahun pelajaran 2018/2019 diperoleh bahwa masih terdapat banyak kekurangan dalam membuat dan mengembangkan perangkat pembelajaran tersebut. Pengembangan komponen pembelajaran yang dapat menjadi contoh dan membantu guru dalam proses belajar mengajar yang sesuai dengan kebutuhan peserta didik dalam lingkungannya sangat diperlukan.

Penelitian yang dilakukan oleh Yustianingsih \& Syarifuddin, (2017) dan Baharuddin (2014) diperoleh bahwa perangkat pembelajaran menggunakan model PBL untuk meningkatkan kemampuan pemecahan masalah matematis yang valid, praktis, dan efektif yang di uji cobakan kepada peserta didik kelas VIII SMP N 3 Sawahlunto dan MTs Model Makassar. Penelitian ini sejalan dengan kedua penelitian tersebut, penelitian yang dillakukan memiliki perbedaan yaitu menambahkan keterampilan abad 21. Salah satu keterampilan abad 21 yang dituntut adalah pemecahan masalah. Pada matematika keterampilan pemecahan masalah dikenal dengan keterampilan pemecahan masalah matematis. Berdasarkan alasan ini, peneliti pengembangan perangkat pembelajaran matematika terintegrasi keterampilan abad 21 melalui penerapan model Problem Based
Learning (PBL) untuk meningkatkan kemampuan pemecahan masalah matematis peserta didik SMP/MTs Kelas VIII pada materi Statistika.

Model PBL memberikan tantangan kepada peserta didik bekerja bersama dalam suatu kelompok untuk menyelesaikan permasalahan. Permasalahan ini digunakan untuk memberikan tantangan kepada peserta didik tentang keingintahuan untuk menyelesaikan suatu masalah. Penelitian ini merupakan penelitian pengembangan perangkat pembelajaran matematika pada materi statistika di kelas VIII SMP/MTs dengan mengacu pada model pengembangan Plomp (Maimunah et al., 2018). Penelitian pengembangan perangkat pembelajaan dilakukan dengan mengintegrasikan keterampilan pada abad 21 melalui penerapan model Problem Based Learning (PBL) untuk meningkatkan kemampuan pemecahan masalah matematis peserta didik SMP/MTs.

\section{Metode Penelitian}

Penelitian ini menggunakan model pengembangan Plomp. Adapun fase-fase pengembangan model Plomp (dalam Maimunah, dkk 2017) terdiri 3 fase. Pada fase investigasi awal (preliminary research) dilakukan analisis kurikulum, analisis materi dan analisis terhadap peserta didik. Pada fase prototype (prototyping phase) yang dilakukan adalah merancang perangkat pembelajaran dan memvalidasi perangkat sehingga menghasilkan prototype. Pada fase penilaian (assessment phase), dilakukan uji coba terbatas dan uji coba lapangan untuk melihat tingkat kepraktisan dan keefektifan produk. Instrumen kevalidan adalah perangkat pembelajaran yang terdiri dari silabus, RPP dan LKPD menggunakan lembar validasi. Instrumen kepraktisan adalah angket respon guru dan peserta didik, serta soal tes KPMM

Analisis data yang digunakan meliputi analisis data kualitatif berupa saran dan masukan dari validator digunakan sebagai bahan perbaikan pada tahap revisi. Analisis kuantitatif terdiri dari analisis terhadap lembar penilaian 
JURNAL GANTANG. Maret 2020; V(1): 77 - 85

p-ISSN. 2503-0671

e-ISSN. 2548-5547

perangkat pembelajaran, analisis terhadap angket respon sisiwa dan guru, serta analisis terhadap hasil tes KPMM peserta didik. Data kevalidan menggunakan rumus sebagai berikut.

$$
M_{v}=\frac{\sum_{i=1}^{n} V_{i}}{n} \quad \text { (Sudijono, 2011) }
$$

Keterangan:

$$
\begin{array}{ll}
M_{v} & =\text { rata- rata total validitas } \\
V_{i} & =\text { Mean validitasi validator ke-i } \\
n & =\text { banyak validator }
\end{array}
$$

Penentuan Mean validitas perangkat pembelajaran yang digunakan dapat dilihat pada tabel berikut.

Tabel.1 Kriteria validitas perangkat pembelajaran

\begin{tabular}{lc}
\hline Interval & Kategori \\
\hline $3,25 \leq \mathrm{x}<4$ & Sangat Valid \\
\hline $2,50 \leq \mathrm{x}<3,25$ & Valid \\
\hline $1,75 \leq \mathrm{x}<2,50$ & Kurang Valid \\
\hline $1,00 \leq \mathrm{x}<1,75$ & Tidak Valid \\
\hline
\end{tabular}

(Sumber: Sugiyono, 2012)

Data kepraktisan perangkat pembelajaran diperoleh dari angket respon peserta didik dan guru. Analisis data hasil respon peserta didik dan guru dilakukan untuk menilai kepraktisan perangkat yang dikembangkan. Analisis data hasil dari angket respon peserta didik dan guru menggunakan rumus sebagai berikut.

$$
V_{p}=\frac{T_{s p}}{T_{s h}} \times 100 \% \quad(\text { Akbar, 2015) }
$$

Keterangan:

$V p=$ skor responden

$T_{s p}=$ total skor empiris dari responden

$T_{s h}=$ total skor maksimal yang diharapkan

Adapun kriteria kepraktisan dari perangkat pembelajaran adalah sebagai berikut.

Tabel. 2 Kriteria kepraktisan perangkat pembelajaran

\begin{tabular}{cc}
$\begin{array}{c}\text { Kriteria } \\
\text { Praktikalitas }\end{array}$ & $\begin{array}{c}\text { Tingkat } \\
\text { Praktikalitas }\end{array}$ \\
\hline $85,01 \%-100 \%(\mathrm{~A})$ & Sangat Praktis \\
\hline $70,01 \%-85,00 \%(\mathrm{~B})$ & Praktis \\
\hline $50,01 \%-70,00 \%(\mathrm{C})$ & Kurang Praktis \\
\hline $01,00 \%-50,00 \%(\mathrm{D})$ & Tidak Praktis \\
\hline (Sumber : Akbar, 2015$)$ &
\end{tabular}

Data keefektifan perangkat pemebelajaran dilakukan analisis terhadap hasil tes KPMM peserta didik yang ditunjukkan melalui skor yang diperoleh peserta didik setelah mengikuti tes. Hasil tes KPMM peserta didik di kelas eksperimen dibandingkan dengan hasil tes KPMM peserta didik di kelas kontrol. Analisis ini digunakan untuk mengetahui tingkat perbedaan KPMM peserta didik. Untuk menentukan perbedaan tersebut dilakukan analisis statistik uji-t.

\section{Hasil dan Pembahasan}

Penelitian ini menggunakan model pengembangan Plomp yang terdiri dari tiga fase yaitu; (1) fase investigasi awal (preliminary research); (2) fase prototipe (prototyping phase); dan (3) fase penilaian (assessment phase).

Fase investigasi awal dilakukan untuk menentukan masalah dasar yang diperlukan dalam pengembangan perangkat pembelajaran matematika. Pada fase ini dilakukan analisis kurikulum, analisis peserta didik dan analisis materi. Pada bagian Analisis Kurikulum dilakukan telaah terhadap kurikulum yang berlaku disekolah. Kurikulum yang berlaku adalah Kurikulum 2013 dan dijadikan pedoman dalam penelitian pengembangan ini. Kegiatan yang dilakukan pada tahap ini adalah analisis kurikulum untuk memperoleh informasi tentang perangkat pembelajaran yang digunakan oleh guru.

Hasil wawancara dengan guru matematika diperoleh informasi bahwa guru mengalami kesulitan dalam menyusun perangkat pembelajaran. Guru kesulitan dalam mengembangkan indikator pencapaian kompetensi yang mengacu pada KD. Menurut Scristia (2019) indikator menggunakan Kata Kerja Operasional (KKO) yang dapat diukur dan/atau di observasi. Selanjutnya guru kesulitan dalam merumuskan tujuan pembelajaran, dan mengembangkan kegiatan pembelajaran dengan menerapkan model pembelajaran yang memfasilitasi peserta didik untuk berpartisipasi aktif dalam proses pembelajaran. Lembar Kerja 
Peserta Didik (LKPD) tidak menggambarkan model pembelajaran yang digunakan. Lembar Kerja Peserta Didik (LKPD) yang digunakan sekolah berisi ringkasan materi dan kumpulan soal-soal. Peserta didik hanya menerima pelajaran yang diberikan oleh guru, kemudian mengerjakan latihan yang ada. Lembar Kerja Peserta Didik (LKPD) seperti ini tidak memberikan mengembangkan kemampuan pemecahan masalah bagi peserta didik.

Peneliti melakukan telaah terhadap Kompetensi Inti dan Kompetensi Dasar yang sesuai dengan kurikulum yang berlaku di sekolah yaitu Kurikulum 2013 untuk menentukan model dan pendekatan pembelajaran yang relevan sehingga diperoleh gambaran model pembelajaran yang sesuai untuk digunakan, dan untuk mengetahui kemampuan yang harus dimiliki oleh peserta didik setelah mempelajari materi tersebut. Sebagai salah satu alternatif, peneliti akan mengembangkan perangkat pembelajaran matematika terintegrasi keterampilan abad 21 melalui penerapan model PBL untuk meningkatkan kemampuan pemecahan masalah matematis peserta didik pada materi statistika kelas VIII SMP.

Kegiatan analisis peserta didik merupakan telaah tentang karakteristik peserta didik yang sesuai dengan rancangan dan pengembangan model pembelajaran. Karakteristik ini meliputi latar belakang pengetahuan, emosi, fisik, sosial dan kemampuan merefleksi yang dimiliki, pengalaman peserta didik baik sebagai kelompok maupun sebagai individu. Dalam analisis kognitif diasumsikan bahwa peserta didik telah memasuki tahap perkembangan operasi formal. Perangkat pembelajaran ini digunakan oleh peserta didik dengan kemampuan tinggi, sedang, maupun rendah. Peserta didik SMP kelas VIII pada umumnya berusia 11-14 tahun. Peserta didik yang berusia diatas 11 tahun telah memiliki kemampuan berfikir abstrak, menalar, dan dapat menyimpulkan. Peserta didik kelas VIII sudah bisa diajarkan dengan menerapkan model PBL.

Materi statistika merupakan satu materi yang diberikan untuk peserta didik kelas VIII. Materi Statistika kelas VIII SMP/MTs pada Kompetensi Dasar (KD)

Tabel 3. Kompetensi dasar materi statistika

\begin{tabular}{cl}
\hline KD & \multicolumn{1}{c}{ Uraian } \\
\hline 3.10 & $\begin{array}{l}\text { Menganalisis data berdasarkan distribusi data, } \\
\text { nilai mean, median, modus, dan sebaran data } \\
\text { untuk mengambil kesimpulan, membuat } \\
\text { keputusan, dan membuat prediksi. }\end{array}$ \\
\hline 4.10 & $\begin{array}{l}\text { Menyajikan dan menyelesaikan masalah yang } \\
\text { berkaitan dengan distribusi data, nilai mean, } \\
\text { median, modus, dan sebaran data untuk } \\
\text { mengambil kesimpulan, membuat keputusan, } \\
\text { dan membuat prediksi }\end{array}$ \\
\hline
\end{tabular}

Hasil wawancara dengan guru matematika diperoleh bahwa penguasaan kemampuan menyelesaikan soal matematika dalam bentuk cerita masih tergolong rendah. Kemampuan pemecahan masalah matematis peserta didik masih tergolong rendah dalam menyelesaikan soal statistika, hal ini terlihat dari kesalahan yang dilakukan oleh peserta didik. Untuk menyelesaikan permasalahan pada materi statistika, dibutuhkan suatu proses yang mendukung sehingga peserta didik dapat menyimpulkan dan mendapatkan pemahaman tentang materi yang dipelajari. Salah satunya dengan penerapan model PBL yang dapat membantu peserta didik dalam memahami masalah dan menyelesaikannya serta meningkatkan kemampuan pemecahan masalah matematis peserta didik.

Fase prototipe (prototyping phase) meliputi menyusun peta kebutuhan meliputi ruang lingkup materi pembelajaran dan alokasi waktu perangkat pembelajaran yang akan dikembangkan. Perangkat pembelajaran akan disusun dalam empat pertemuan dengan materi pembelajaran yaitu: (1) Mean (2) Modus (3) Median (4) Ukuran penyebaran data. Perangkat pembelajaran yang akan dirancang berupa silabus, RPP, dan LKPD berbasis keterampilan abad 21 melalui penerapan model PBL untuk meningkatkan kemampuan pemecahan masalah matematis peserta didik pada materi statistika kelas VIII SMP.

Silabus adalah acuan penyusunan 


\section{JURNAL GANTANG. Maret 2020; V(1): 77 - 85 \\ p-ISSN. 2503-0671 \\ e-ISSN. 2548-5547}

kerangka pembelajaran yang terdiri dari identitas, KI, KD, indikator pencapaian kompetensi, materi pembelajaran, kegiatan pembelajaran, penilaian, alokasi waktu, dan sumber belajar. KI dan KD dalam silabus mengacu pada Permendikbud Nomor 24 Tahun 2016 tentang Kompetensi Inti dan Kompetensi Dasar Pelajaran pada Kurikulum 2013. Indikator Pencapaian Kompetensi (IPK) dirumuskan dengan menggunakan kata kerja operasional yang dapat diamati dan diukur yang mencakup pengetahuan dan keterampilan. Kegiatan pembelajaran terintegrasi keterampilan abad 21 melalui penerapan model PBL dengan pendekatan saintifik untuk meningkatkan kemampuan pemecahan masalah matematis peserta didik. Penilaian pengetahuan diukur menggunakan tes tertulis, tes lisan, dan penugasan yang terintegrasi dalam proses pembelajaran. Penilaian keterampilan menggunakan teknik lain untuk mengukur keterampilan peserta didik dalam ranah pemecahan masalah matematis dengan memberikan soal uraian dan menggunakan rubrik penilaian keterampilan.

\section{Rencana Pelaksanaan Pembelajaran} (RPP) dikembangkan dari silabus untuk mengarahkan kegiatan pembelajaran peserta didik dalam upaya mencapai KD. Zuhri, dkk (2019) mengatakan bahwa Rencana Pelaksanaan Pembelajaran (RPP) adalah panduan bagi seorang guru dalam mengimplementasikan proses pembelajaran. Rencana Pelaksanaan Pembelajaran (RPP) disusun untuk empat pertemuan dengan materi pembelajaran yaitu: (1) Mean (2) Median (3) Modus (4) Ukuran Penyebaran Data. Tujuan pembelajaran dirumuskan secara jelas yang didalamnya mencakup komponen Audience, Behaviour, Conditioning, dan Degree. Kegiatan pembelajaran dalam RPP disusun berdasarkan Permendikbud Nomor 22 Tahun 2016 tentang Standar Proses Pendidikan Dasar dan Menengah dengan menerapkan model PBL dan pendekatan scientific, memuat kemampuan 4C (Critical Thinking and Problem Solving Skill,
Communication Skills, Creativity and Innovation, dan Collaboration). Kemampuan tersebut terintegrasi dalam kegiatan pembelajaran dengan penerapan model PBL dan pendekatan scientific melalui mengamati, menanya, mengumpulkan informasi, menalar, dan mengkomunikasikan.

Penilaian yang diukur meliputi penilaian pengetahuan dan penilaian keterampilan. Penilaian pengetahuan dilakukan dengan tes tertulis yang diberikan kepada peserta didik setelah mengikuti proses pembelajaran. Tes lisan dilakukan dalam bentuk tanya jawab dalam proses pembelajaran, dan penugasan dilakukan secara individu maupun kelompok setelah proses pembelajaran berakhir. Penilaian keterampilan menggunakan teknik lain untuk mengukur keterampilan peserta didik dalam ranah berpikir dengan memberikan soal uraian dan menggunakan rubrik penilaian keterampilan.

LKPD dirancang untuk empat kali pertemuan LPKD) yang dirancang disesuaikan dengan model PBL dan kegiatan yang memuat indikator kemampuan pemecahan masalah matematis pada materi statistika. Peneliti mendesain LKPD yang dilengkapi dengan kolom-kolom yang berisi materi yang berkaitan dengan materi pembelajaran. Pada kolom "Ayo kita amati”. Masalah yang disajikan adalah masalah dalam kehidupan sehari-hari yang melibatkan KPMM. Pada kolom "ayo kita nenanya". Pada kolom "ayo kita menanya" peserta didik diminta untuk menuliskan apa yang diketahui dan ditanya dari masalah yang diamati. Peserta didik diminta untuk menyelesaikan langkah demi langkah pada kolom "ayo mengumpulkan informasi" untuk memperoleh informasi yang digunakan untuk menyelesaikan masalah. Setelah peserta didik memperoleh informasi yang dibutuhkan, peserta didik diminta untuk membuat rencana pemecahan masalah selanjutnya menuliskan pemecahan masalah pada kolom "Ayo kita menalar". Selanjutnya pada kolom "ayo kita simpulkan" peserta didik diminta untuk membuat kesimpulan yang diperoleh. Selanjutnya pada kolom "ayo kita 
berlatih" peserta didik diminta untuk berlatih mengerjakan soal yang diberikan.

Setelah perangkat pembelajaran telah diproduksi, selanjutnya dilakukan penilaian terhadap perangkat pembelajaran yang dikembangkan. Berikut hasil validasi silabus.

HASIL VALIDASI SILABUS

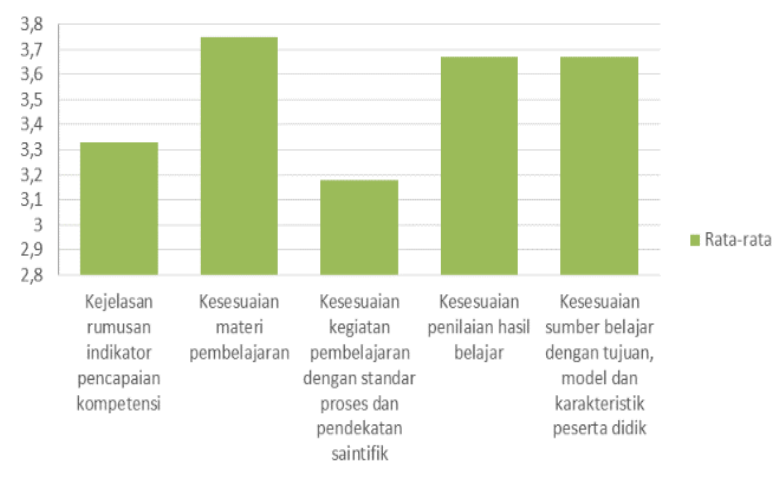

Gambar 1. Hasil validasi silabus

Rata rata hasil validitas silabus dari validator diperoleh nilai 3,51 dengan kriteria sangat valid. Adapun hasil validasi RPP oleh validator adalah sebagai berikut.

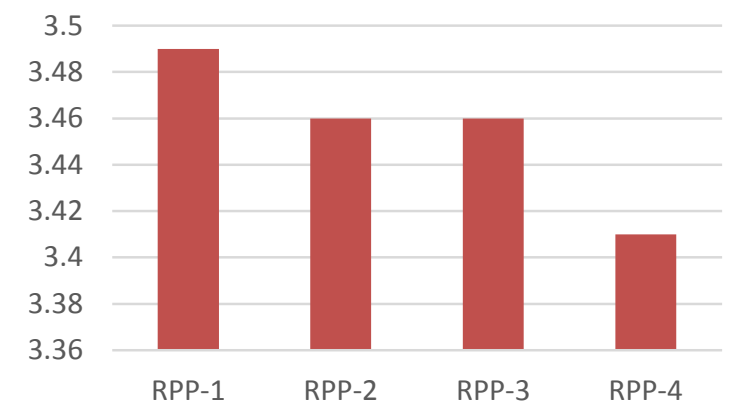

Gambar 2. Hasil validasi RPP

Hasil validasi menunjukkan bahwa RPP untuk empat pertemuan memenuhi kriteria sangat valid dengan persentase rata-rata dari RPP-1 yaitu 3,49; RPP-2 yaitu 3,46 ; RPP-3 yaitu 3,46; dan RPP-4 yaitu 3,41. Hasil penilaian RPP oleh validator diperoleh rata-rata nilai 3,46 dengan kriteria sangat valid. Selanjutnya berikut adalah hasil penilaian terhadap LKPD.

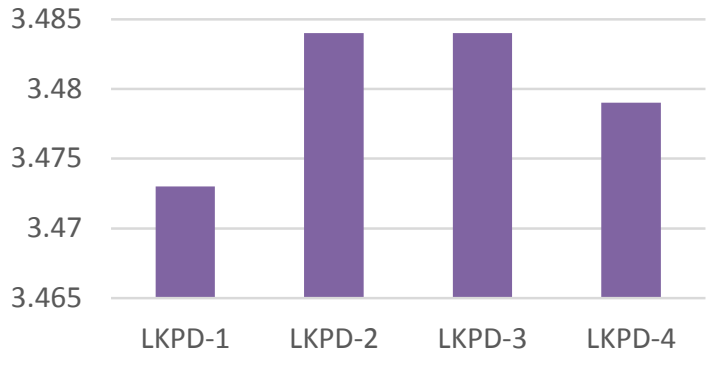

Gambar 3. Hasil validasi LKPD

Penilaian terhadap LKPD-1 diperoleh niilai 3,47; RPP-2 yaitu 3,48; RPP-3 yaitu 3,48 dan RPP-4 yaitu 3,48. Penilaian terhadap LKPD diperoleh rata-rata nilai 3,48 yang menunjukkan kriteria sangat valid. Adapun hasil penilaian terhadap soal tes kemampuan pemecahan masalah matematis adalah sebagai berikut.

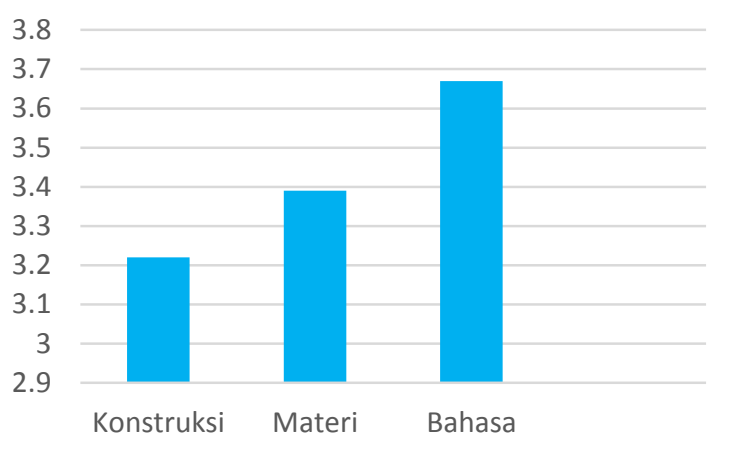

Gambar 4. Hasil validasi soal KPMM

Penilaian terhadap soal kemampuan pemecahan masalah diperoleh rata-rata 3,43 dengan kriteria sangat valid. Meski telah sangat valid, saran dan masukan yang diberikan oleh validator ditindak lanjuti dengan memperbaiki perangkat sesuai dengan saran yang diberikan.

Fase penilaian, meliputi uji coba untuk melihat kepraktisan dan keefektifan produk yang dikembangkan. Uji coba dilakukan dua kali yaitu uji coba terbatas (kelompok kecil) dan uji coba lapangan (kelompok besar).Uji coba kelompok kecil dilakukan untuk melihat keterbacaan LKPD yang dikembangkan. Peserta didik bekerja menyelesaikan masalah yang ada pada LKPD dengan kelompok kecil yang terdiri dari 8 orang. Hasil respon peserta didik melalui angket praktikalitas didapatkan persentase sebesar 


\section{JURNAL GANTANG. Maret 2020; V(1): 77 - 85 \\ p-ISSN. 2503-0671 \\ e-ISSN. 2548-5547}

91,00\% dengan kriteria sangat praktis. Meski dikatakan praktis, saran dan masuk dari peserta didik diperbaiki sesuai yang disarankan.Masukan dan saran yang diberikan dari kelompok kecil sebagian besar mengenai kesalahan ketikan dan kalimat perintah yang ada pada LKPD masih sulit dimengerti dan kurangnya tempat utk menjawab soal pada LKPD. Peneliti mengacu kepada hasil pengamatan saat peserta didik mengerjakan LKPD, angket respon, serta hasil diskusi dengan peserta didik. Salah satu komentar peserta didik terhadap LKPD yang dikembangkan seeprti berikut.

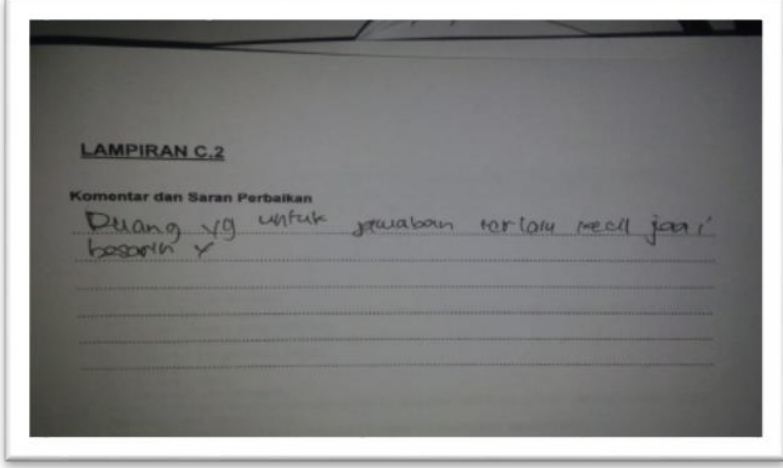

Gambar 5 . Komentar dan saran peserta didik terhadap LKPD

Peneliti selanjutnya, melakukan revisi terhadap LKPD. Revisi yang dilakukan meliputi perbaikan terhadap kesalahan ketikan, perbaikan pada kolom jawaban peserta didik yang dinilai terlalu kurang mencukupi. Saran dan masukan tersebut direvisi sebelum dilakukan uji coba kelompok besar.

Uji coba kelompok besar dilakukan terhadap peserta didik yang terdiri dari 33 orang dari kelas VIII.8. Uji coba kelompok dilakukan dengan menggunakan perangkat pembelajaran berupa RPP dan LKPD pada kegiatan pembelajaran. Hasil respon peserta didik dari kelompok besar melalui angket praktikalitas menunjukkan nilai persentase sebesar $92,50 \%$ dengan kriteria sangat praktis. Selain itu, dilakukan pengamatan oleh guru terhadap keterlaksanaan kegiatan pembelajaran yang telah dirancang sebelumnya. Pengamatan keterlaksanaan kegiatan pembelajaran yang diamati oleh guru bidang studi matematika melalui lembar pengamatan. Berdasarkan hasil pengamatan yang dilakukan oleh guru, didapatkan bahwa sebagian besar kegiatan yang terdapat pada RPP telah dilaksanakan sesuai dengan rancangan yang telah dibuat dalam RPP. Respon guru terhadap perangkat pembelajaran didapatkan melalui angket respon guru dengan hasil persentase sebesar 93,50\% dengan kriteria sangat praktis.

Tahap uji produk akhir dilakukan menggunakan penelitian pre-eksperimen dengan desain Static Group Comparison. Hasil uji produk akhir menunjukkan bahwa kemampuan pemecahan masalah matematis peserta didik pada kelas eksperimen lebih baik daripada kelas kontrol. Hasil penelitian yang telah dilakukan menunjukkan bahwa perangkat pembelajaran terintegrasi keterampilan abad 21 melalui penerapan model Problem Based Learning(PBL) untuk meningkatkan kemampuan pemecahan masalah matematis pada materi statistika kelas VIII SMP sudah valid, praktis dan efektif.

\section{Kesimpulan}

Penelitian pengembangan ini menghasilkan perangkat pembelajaran matematika terintegrasi keterampilan abad 21 melalui penerapan model Problem Based Learning (PBL) untuk meningkatkan kemampuan pemecahan masalah matematis peserta didik pada materi statistika kelas VIII SMP. Perangkat pembelajaran dikatakan sangat valid, sangat praktis dan efektif setelah melalui proses validasi oleh para ahli yang berkualitas, dan peserta didik kelas VIII untuk memastikan kepraktisan perangkat pembelajaran yang dikembangkan.

\section{Referensi}

Aji, M. Q. W. (2019). Mengembangkan kecakapan abad 21 mahasiswa melalui model pembelajaran inkuiri. Teknodika. https://doi.org/10.20961/teknodika.v17i2.3 5281

Akbar, S. (2015). Instrumen Perangkat Pembelajaaran. Remaja Rosdakarya.

Baharuddin. (2014). Pengembangan perangkat pembelajaran matematika materi segiempat berbasis model kooperatif tipe stad 
denganmetode penemuan terbimbing kelas Vii Mts Negeri Model Makassar. MaPan.

D, Z., Maimunah, M., \& Yuanita, P. (2020). The development of math learning tools for elementary based on 2013 curriculum in coastal area. Journal of Educational Sciences. https://doi.org/10.31258/jes.4.1.p.133-145

Kunandar. (2014). Penilaian Autentik. Rajawali Pres.

Maimunah. (2016). Pengembangan model pembelajaran matematika melalui pemecahan masalah untuk mengembangkan penalaran matematis peserta didik. UNM.

Maimunah, M., Solfitri, T., \& Yuanita, P. (2018). Pengembangan perangkat pembelajaran melalui pemecahan masalah untuk meningkatkan penalaran matematis mahasiswa program studi pendidikan matematika jurusan PMIPA FKIP Universitas Riau. Al-Khwarizmi: Jurnal Pendidikan Matematika Dan Ilmu Pengetahuan Alam. https://doi.org/10.24256/jpmipa.v5i1.263

Noviantii, E., Yuanita, P., \& Maimunah, M. (2020). Pembelajaran berbasis masalah dalam meningkatkan kemampuan pemecahan masalah matematika. Journal of Education and Learning Mathematics Research (JELMaR). https://doi.org/10.37303/jelmar.v1i1.12

Putri, A., Roza, Y., \& Maimunah, M. (2020). Development of learning tools with the discovery learning model to improve the critical thinking ability of mathematics. Journal of Educational Sciences. https://doi.org/10.31258/jes.4.1.p.83-92

Scristia, S. (2019). Analisis kesesuaian indikator terhadap kompetensi dasar pada pelajaran matematika oleh guru sekolah menengah Palembang. Jurnal Gantang. https://doi.org/10.31629/jg.v4i2.1429

Sudijono, A. (2011). Pengantar Statistik. Rajawali Pres.

Sugiyarti, L., Arif, A., \& Mursalin. (2018). Pembelajaran abad 21 di SD. Prosiding Seminar dan Diskusi Nasional Pendidikan Dasar.

Sugiyono. (2012). Metode Penelitian Kuantitatif, Kualitatif dan $R \& D$. Alfabeta.

Sumarmo, U. (2014). Berpikir dan disposisi matematika serta pembelajarannya. Kumpulan Makalah Pendidikan Matematika FPMIPA UPI Bandung. https://doi.org/10.1109/SECPRI.2000.8484 45

Trianto. (2009). Mendesain model pembelajaran inovatif - progresif. Kencana Prenada Media Group.

Yustianingsih, R., \& Syarifuddin, H. (2017). Pengembangan perangkat pembelajaran matematika berbasis problem based learning ( PBL ) untuk meningkatkan kemampuan pemecahan masalah. I(2), 258-274. 